Saken ŻUMANOWICZ NURBEKOW

Kazachski Uniwersytet Narodowy im. Al-Farabi

\title{
Prawne aspekty dzialalności Środków Masowej Informacji w Europie i Kazachstanie: problemy implementacji i realizacji
}

\footnotetext{
$\mathrm{O}$
} becnie w Republice Kazachstanu gotowe są podstawy prawne w sferze wolności słowa, zdobywania, opracowywania i rozpowszechniania informacji, organizacji i działalności dziennikarzy i środków masowego przekazu. Mają one współcześnie pozytywną tendencję rozwoju.

Stymulujący wpływ na ten proces wywiera szereg czynników obiektywnych. Do katalizatorów zalicza się stopniowa demokratyzacja i modernizacja, wchodzenie Kazachstanu w cywilizowaną przestrzeń międzynarodową, ratyfikacja ogólnie uznawanych międzynarodowych i regionalnych dokumentów dotyczących praw i wolności człowieka i obywatela, ruchu transgranicznego, przepływu informacji i in. Wśród organów władzy państwowej stopniowo zmienia się stosunek do środków masowego przekazu, w strukturach państwowych kształtują się specjalne działy współpracy z dziennikarzami, oficjalna informacja jest rozpowszechniana w różnorodnych formach, w tym przez Internet. Realizowany jest program udostępniania informacji przez rząd drogą elektroniczną, w podobny sposób rozwija się jawność rozpraw sądowych.

Lata 2006-2007 charakteryzowały się szeroko zakrojoną dyskusją na temat dalszego rozwoju Kazachstanu w kierunku demokracji. Podsumowaniem było zatwierdzenie przez prezydenta dwóch bardzo ważnych dla niniejszych rozważań dokumentów: „Koncepcji rozwoju społeczeństwa obywatelskiego na lata 2006-2011” i ,Koncepcji rozwoju konkurencyjności przestrzeni informacyjnej Republiki Kazachstanu na lata 2006-2009”. Kolejnym krokiem było przyjęcie 21 maja 2007 r. ustawy „O zmianach i uzupełnieniach w Konstytucji Republiki Kazachstanu”. Wyżej wymienione czynniki kształtuja liberalny wektor rozwoju ustawodawstwa dotyczącego środków masowego przekazu w Kazachstanie.

Stymulujący wpływ, mający jednakże inny charakter, wynika ze współczesnych wyzwań w obliczu kryzysu gospodarczego, ekstremizmu politycznego, narodowego i religijnego, konieczności ochrony praw czło- 
wieka i obywatela, zachowania i utrwalenia kulturowej tożsamości Kazachstanu. Obok takich czynników nie sposób przejść obojętnie i pozostawić je bez komentarza i oceny. Przy tym jednakże w tworzeniu norm i praktyce wdrażania prawa nie zawsze jest zachowana zasada proporcji między imperatywami i istniejącymi ograniczeniami. W związku z tym Rada Konstytucyjna podjęła szereg decyzji.

Sferę informacyjną jako całość oraz mass media jako jej element cechuje wzrost dynamiki i wewnętrzne sprzeczności, co wymaga zachowania równowagi w wielu aspektach. Należy do nich: otwartość władzy państwowej a interesy państwa; wolność słowa i rozpowszechniania informacji a prawa człowieka; dążenie dziennikarza do opisania wszystkiego a ograniczenie tego dążenia przez prawnie chronione interesy obywateli i osób prawnych; dążenie każdego do pozyskiwania i dalszego przekazywania dowolnej interesującej go informacji a zapewnienie ochrony jednostki od okrucieństwa, pornografii, rasizmu, nacjonalizmu i ekstremizmu; wewnętrzna rzeczywistość dziennikarstwa i ogólnie przyjęte normy etyki zawodowej a standardy konkretnego wydawnictwa i jego właścicieli, i wiele innych, nie mówiąc już o powszechnie znanych skutkach globalizacji, konstytucyjnych wartościach jednych grup społeczności i nieadekwatnym postrzeganiu ich przez inne (w takiej kwestii wartościowanie jako „dobry” lub „zły” jest w ogóle nie na miejscu). Patrząc z tej pozycji, dzisiejsze czasy w skali globalnej można uznać za nienajlepsze dla tradycyjnego pojęcia wolności mediów.

Dobrze znane są sprzeczności w ocenie roli środków masowego przekazu jako narzędzia walki politycznej i jako odmiany zwykłego biznesu. Istnieją także zagadnienia natury czysto prawnej, np. sposób uporządkowania poszczególnych aktów regulacji prawnej: które z nich powinno się umieścić na poziomie konstytucji, które na poziomie ustawy, które zaś na poziomie aktu prawnego niższej rangi niż ustawa. Im niżej w hierarchii aktów prawnych, tym więcej pojawia się podobnych pytań. Zdaniem autora, im wolniej będzie się rozwijać samorządność mediów, tym dłużej zachowają się przekonania świadczące na korzyść silnej pozycji państwa, imperatywnych metod regulacji prawnych, z zakazami i odpowiedzialnością dziennikarską włącznie.

Zadaniem regulacji prawnych jest więc uporządkowanie w miarę możliwości licznych sprzeczności i budowa efektywnego systemu hamulców i równowagi.

Podstawę ustawodawstwa Republiki Kazachstanu dotyczącego wolności słowa i informacji stanowią wartości, idee i zasady zatwierdzone w konstytucji przyjętej przez ogólnonarodowe referendum z 30 sierpnia 1995 r.: 
- w preambule: zapis o pokojowym społeczeństwie obywatelskim przywiązanym do ideałów wolności, równości i zgody, pragnącym zająć godne miejsce w społeczności międzynarodowej i zdające sobie sprawę ze stojącej przed nim wielkiej odpowiedzialności;

- w art. 1 rozdziału I „Zasady ogólne”: zapis o Republice Kazachstanu jako demokratycznym świeckim i socjalnym państwie prawa, w którym najważniejszą wartością jest człowiek, jego życie, prawa i wolności, a także o podstawowych zasadach funkcjonowania państwa: art. 4 -system prawny, w tym ratyfikowane przez Kazachstan umowy międzynarodowe; art. 5 - pluralizm ideologiczny i polityczny; art. 6, 7 i 8 - równość form własności, status języków, poszanowanie przez Kazachstan zasad i norm prawa międzynarodowego;

- w rozdziale II „Człowiek i obywatel”: art. 12 - uznanie i gwarancja praw i wolności człowieka w zgodzie z konstytucją; art. 20 - gwarancja wolności słowa i twórczości, prawo każdego człowieka do pozyskiwania i rozpowszechniania informacji na wszelkie niezabronione przez prawo sposoby, a także konstytucyjne zakazy dotyczące tej sfery; inne artykuły regulujące zbliżone do wyżej wymienionych prawa konstytucyjne, wolności i obowiązki człowieka i obywatela w Republice Kazachstanu. Szczególnie należy podkreślić art. 39 dotyczący możliwości ograniczenia praw i wolności ,wyłącznie przez prawo i wyłącznie w takim stopniu, w jakim jest to niezbędne w celach ochrony porządku konstytucyjnego i publicznego, praw i wolności człowieka, zdrowia i moralności ludności"1.

Wszystkie pozostałe normy konstytucyjne zawarte w rozdziałach poświęconych organom państwowym wywodzą się z zapisów preambuły i rozdziału I. Innymi słowy, prezydent Republiki Kazachstanu, parlament, rząd, Rada Konstytucyjna, sądy, lokalne organy władzy państwowej i organy samorządu terytorialnego, a zatem i osoby w nich pracujące, w każdej decyzji i każdym działaniu powinni kierować się normami Ustawy Zasadniczej przyjętej przez ogólnokrajowe referendum.

Na podstawie konstytucji, w zgodzie z nią i w dążeniu do rozwoju idei, zasad i norm w niej zawartych przyjmuje się poszczególne akty prawne.

- Ustawy: „O środkach masowego przekazu” z 23 lipca 1999 r. (ze zmianami i uzupełnieniami z 27 lutego 2001 r., 3 maja 2001 r., 19 grudnia 2003 r., 8 lipca 2005 r., 10 stycznia 2006 r., 31 stycznia 2006 r., 5 lipca

1 Konstytucja Republiki Kazachstanu (przyjęta na ogólnonarodowym referendum 30 sierpnia 1995 r., ze zmianami i uzupełnieniami z 21 maja 2007 r.). 
2006 r., 19 czerwca 2007 r. i 6 lutego 2009 r.). Przedmiotem ustawy są regulacje państwowe $\mathrm{w}$ sferze środków masowego przekazu (art. 4.1-4.5), organizacja działalności środków masowego przekazu (art. 5-13), rozpowszechnianie środków masowego przekazu (art. 14-16), stosunki środków masowego przekazu z obywatelami i organizacjami (art. 17-19), prawa i obowiązki dziennikarzy (art. 20-21), akredytacja dziennikarzy (art. 22-24), a także odpowiedzialność za naruszenie prawa o środkach masowego przekazu (art. 25-26)

Inne ustawy, np. „O informatyzacji” z 11 stycznia 2007 r., „O łączności” z 5 lipca 2004 r.

Szczególne miejsce w regulacji prawnej mediów zajmuje ustawa „O zmianach i uzupełnieniach w niektórych aktach prawnych Republiki Kazachstanu dotyczących sieci informacyjno-komunikacyjnych” z 10 lipca 2009 r., zwana w skrócie ,ustawą o regulacji Internetu”. Zmiany wniesiono w piętnaście ustaw. Zasoby Internetu zrównano ze środkami masowego przekazu z wszelkimi wynikającymi z tego skutkami: ograniczeniami rozprzestrzeniania informacji zabronionych przez prawo i możliwymi sankcjami prawnymi dla sprawców takich naruszeń. Decyzję o nałożeniu sankcji, w tym najdalej idących - wstrzymaniu lub zlikwidowaniu działalności danego medium - ma prawo podejmować wyłącznie sąd.

- Akty prezydenta Republiki Kazachstanu zatwierdzone przez rozporządzenia głowy państwa: „Koncepcja rozwoju społeczeństwa obywatelskiego na lata 2006-2011" (rozporządzenie z 25 lipca 2006 r.), „Koncepcja rozwoju konkurencyjności przestrzeni informacyjnej Republiki Kazachstanu na lata 2006-2009" (rozporządzenie z 18 sierpnia 2006 r.), „Koncepcja bezpieczeństwa informacyjnego w Republice Kazachstanu (rozporządzenie z 10 października 2006 r.) ) $^{3}$.

- Liczne akty normatywno-prawne rządu Republiki Kazachstanu, ministerstwa kultury i informacji i innych organów.

Zatwierdzone przez rząd Republiki Kazachstanu następujące akty: „Zasady przeprowadzania konwersji widma fal radiowych i metodyki technicz-

2 Ustawa „O środkach masowego przekazu” z 23 lipca 1999 r. (ze zmianami i uzupełnieniami z 27 lutego 2001 r., 3 maja 2001 r., 19 grudnia 2003 r., 8 lipca 2005 r., 10 stycznia 2006 r., 31 stycznia 2006 r., 5 lipca 2006 r., 19 czerwca 2007 r. oraz 6 lutego 2009 r.).

3 (Rozporządzenie z 25 lipca) „Koncepcja rozwoju konkurencyjności przestrzeni informacyjnej Republiki Kazachstanu na lata 2006-2009” (rozporządzenie prezydenta Republiki Kazachstanu z 18 sierpnia 2006 r.), „Koncepcja bezpieczeństwa informacyjnego Republiki Kazachstanu” (rozporządzenie prezydenta Republiki Kazachstanu z 10 października 2006 r.). 
no-ekonomicznego uzasadnienia wydatków na przeprowadzanie konwersji widma fal radiowych” z 27 czerwca 2009 r., ,Zasady licencjonowania i wymagania kwalifikacyjne dla radiofonii i telewizji” z 18 lipca 2007 r., „Status Międzyresortowej Komisji ds. Częstotliwości Radiowych Republiki Kazachstanu” z 21 maja 2002 r., ,Zasady udzielania i publikacji przez centralne organy administracji państwowej Republiki Kazachstanu oficjalnych informacji” z 12 czerwca 2001 r., ,Zasady rejestracji zagranicznych środków masowego przekazu nadających na terenie Republiki Kazachstanu".

Następujące akty zostały zatwierdzone przez ministra kultury, informacji i zgody społecznej: „Porządek ustalania nominałów (kanałów) częstotliwości radiowych na cele radiofonii i telewizji w Republice Kazachstanu” z 8 listopada 1999 r., ,Zasady akredytacji dziennikarzy środków masowego przekazu i agencji informacyjnych przy organach władzy państwowej i innych organizacjach” z 5 stycznia 2000 r., ,Zasady archiwizacji nagrań telewizyjnych i radiowych mających wartość historyczną lub kulturową".

Wspólnym rozporządzeniem wydanym przez prezesa Agencji Informatyzacji i Łączności Republiki Kazachstanu (15 lipca 2004 r.) i ministra obrony (30 lipca 2004 r.) są „Zasady udostępniania pasem częstotliwości radiowych rozgłośniom analogowym i cyfrowym wszelkiego przeznaczenia na terytorium Republiki Kazachstanu".

- W życie wchodzą ratyfikowane przez Kazachstan dokumenty: Międzynarodowy Pakt Praw Obywatelskich i Politycznych, europejska konwencja o telewizji transgranicznej, konwencja o statusie korespondenta reprezentującego środek masowego przekazu państwa członkowskiego WNP w innych państwach tej organizacji, porozumienie między państwami członkowskimi organizacji „Współpraca Centralnoazjatycka” o wzajemnym rozpowszechnianiu programów telewizyjnych i radiowych, porozumienie o współpracy państw członkowskich WNP w sferze czasopism, dokumenty OBWE i UNESCO ${ }^{4}$.

Oprócz specjalnego ustawodawstwa dotyczącego środków masowego przekazu i zapewnienia wolności słowa i informacji bezpośredni wpływ na media wywierają także zapisy innych aktów prawa:

- wyborczego - ustawy konstytucyjnej z 28 września 1995 r. „O wyborach w Republice Kazachstanu", aktów Centralnej Komisji Wyborczej (np. o zasadach przeprowadzania kampanii wyborczej w środkach ma-

${ }^{4}$ Europejska konwencja o telewizji transgranicznej (Seria Traktatów Rady Europy nr 132, Strasburg, 5 maja 1989). 
sowego przekazu i zabezpieczenia informacyjnego wyborów posłów do Mażylisu Parlamentu Republiki Kazachstanu);

- cywilnego - kodeksu cywilnego, który został zatwierdzony przez uchwałę Najwyższej Rady Republiki Kazachstanu z 27 grudnia 1994 r. oraz kodeksu cywilnego (część szczegółowa) z 1 lipca 1999 r., w szczególności prawa własności intelektualnej, praw autorskich i innych zbliżonych praw, ochrony honoru, godności i dobrego imienia, rejestracji osób prawnych i in., a także decyzji normatywnej Sądu Najwyższego Republiki Kazachstanu z 18 grudnia 1992 r. „O zastosowaniu prawa o ochronie honoru, godności i dobrego imienia osób fizycznych i prawnych w praktyce sądowej";

- karnego - kodeksu karnego z 16 lipca 1997 r., w szczególności przepisów o odpowiedzialności karnej za oszczerstwo;

- administracyjnego - kodeksu o naruszeniach prawa administracyjnego z 30 stycznia 2001 r. - przepisów o odpowiedzialności środków masowego przekazu za przestrzeganie obowiązującego prawa, a także o opiece socjalnej, licencjonowaniu, działalności antymonopolowej i in.;

- postępowania sqdowego - o jawności procesów sądowych; w sprawach cywilnych - kodeks postępowania cywilnego z 13 lipca 1999 r., w sprawach karnych - kodeks postępowania karnego z 13 grudnia 1997 r., w sprawach administracyjnych - kodeks postępowania administracyjnego z 30 stycznia 2001 r. Funkcjonują także normatywne decyzje Sądu Najwyższego Republiki Kazachstanu: „O przestrzeganiu zasady jawności postępowania sądowego w sprawach cywilnych" z 28 października 2005 r., „O przestrzeganiu zasady jawności postępowania sądowego w sprawach karnych" oraz postanowienie plenum Sądu Najwyższego z 14 maja 1998 r. „O niektórych kwestiach zastosowania ustawy o władzy sądowniczej w Republice Kazachstanu”;

- w sferze bezpieczeństwa narodowego - ustawa „O bezpieczeństwie narodowym Republiki Kazachstanu” z 26 czerwca 1998 r., „O przeciwdziałaniu ekstremizmowi” z 18 lutego 2005 r. i „O walce z terroryzmem” z 13 lipca 1999 r., a także inne ustawy: o językach, o reklamie i o podatkach.

Należy szczególnie podkreślić, że ustawa „O zmianach i uzupełnieniach w niektórych aktach prawnych Republiki Kazachstanu dotyczących środków masowego przekazu” liberalizowała szereg przepisów ustawy „O środkach masowego przekazu”, kodeksu cywilnego i kodeksu administracyjnego.

Według art. 4 konstytucji Republiki Kazachstanu do obowiązującego prawa zaliczają się postanowienia Rady Konstytucyjnej Republiki Ka- 
zachstanu. Prawomocne akty normatywne zostały zrównane z zapisami konstytucyjnymi.

Na mocy postanowienia Rady Konstytucyjnej Republiki Kazachstanu $\mathrm{Nr} 4$ z 21 kwietnia 2004 r. w porządku wstępnego rozpatrzenia na wniosek prezydenta Republiki Kazachstanu uznano za niekonstytucyjną ustawę „O środkach masowego przekazu” przyjętą przez parlament 18 marca 2004 r. i przedstawioną do podpisania przez głowę państwa 25 marca 2004 r. Interesujący jest zbiór artykułów konstytucji, które uznano za podstawę decyzji Rady Konstytucyjnej, „które powinny być uznane za podstawę regulacji prawnych stosunków społecznych w sferze działalności środków masowego przekazu: 1) przepisy ogólne (art. 1, 7 i in.), 2) przepisy regulujące konstytucyjne prawa i wolności człowieka i obywatela i odnoszące się do środków masowego przekazu (art. 12, 12, 18, 20, 39 i in.), 3) przepisy wyznaczające zakres działania sądów i wymiaru sprawiedliwości (art. 75-77), 4) przepisy regulujące proces ustawodawczy w Republice Kazachstanu (art. 45, 61, 66)".

Rada Konstytucyjna sprawdziła i uznała za zgodne z konstytucją następujące przepisy ustawy: przepisy zakazujące bezprawnej interwencji w działalność środków masowego przekazu; wymóg określający obowiązkowy udział wymiaru czasowego programów emitowanych przez radio i telewizję w języku urzędowym w ciągu tygodnia, który nie powinien być krótszy niż suma czasu wszystkich programów emitowanych w innych językach, a także ustalenie równomiernego zaplanowania dobowego rozkładu programów nadawanych w języku urzędowym; zakaz ogłaszania w środkach masowego przekazu przedwczesnych wyroków toczących się rozpraw sądowych; ograniczenia dla zagranicznych osób prawnych, obywateli zagranicznych lub bezpaństwowców dotyczące pośredniego bądź bezpośredniego posiadania na własność (i/lub zarządzania) ponad 20\% akcji (udziałów, certyfikatów inwestycyjnych) osoby prawnej będącej właścicielem środka masowego przekazu w Republice Kazachstanu, a także kandydowania i zajmowania stanowiska redaktora naczelnego danego środka masowego przekazu; zbiór praw dziennikarza niezbędnych do realizacji jego działalności zawodowej, a także specjalny status dziennikarza.

Państwo gwarantuje dziennikarzowi w związku z wykonywaniem przezeń działalności zawodowej ochronę honoru, godności, zdrowia, życia i majątku jako osobie ukierunkowanej na osiagnięcie szczególnie pożytecznego celu. Na tej podstawie Rada Konstytucyjna stwierdziła, że niektóre przepisy ustawy „O środkach masowego przekazu” są niezgodne z poszczególnymi zapisami konstytucji: preambuła, która głosi, że „usta- 
wa... jest ukierunkowana na realizację ustanowionego i gwarantowanego przez konstytucję prawa obywateli do wolności słowa, pozyskiwania i rozpowszechniania informacji”. Zdaniem Rady Konstytucyjnej użycie pojęcia „obywatel” zawęża zakres obowiązywania ustawy i prowadzi do niezgodności treści jej preambuły z punktem 2 art. 20 konstytucji; przepisy punktów 1, 4 i 5 art. 29 ustawy zapewniające prawo do sprostowania wyłącznie obywatelom kraju; podpunkt 1) art. 5 ustawy, w którym za główne zasady działalności środków masowego przekazu uznaje się wolność słowa, pozyskiwania i rozpowszechniania informacji na wszelkie sposoby nie podlegające zakazom według ustawodawstwa Republiki Kazachstanu. Powyższe przepisy ustawy dopuszczają ograniczenie wolności słowa oraz prawa do swobodnego pozyskiwania i rozpowszechniania informacji nie tylko przez ustawę, lecz również przez normatywne akty prawne niższej rangi; decyzja o odebraniu licencji na działalność radiofoniczną i telewizyjną i uznanie zaświadczenia o rejestracji środka masowego przekazu za nieważne odbywają się na drodze sądowej (punkt 4 art. 24 i punkt 11 art. 12), natomiast odwołanie zaświadczenia o rejestracji środka masowego przekazu, jak wynika z podpunktu 4) art. 8 ustawy, następuje na mocy decyzji organu mającego uprawnienia w zakresie środków masowego przekazu.

W związku z wyłącznością wyżej wspomnianego środka, może on być podejmowany jedynie przez sądy. Rada Konstytucyjna stwierdziła, że ustawa ma wady odnoszące się do techniki prawnej. Wskutek tej decyzji Rady Konstytucyjnej obecnie funkcjonuje ustawa „O środkach masowego przekazu" z 23 lipca 1999 r. z wymienionymi wyżej zmianami i uzupełnieniami.

Niezbędne jest podkreślenie, że kwestia zapewnienia praw i wolności człowieka i obywatela, zwłaszcza w sferze wyrażania swojej woli i stawania w jej obronie, a także możliwości ograniczania praw i wolności przez parlament drogą przyjęcia ustawy zaczynają stawać się głównym przedmiotem działalności Rady Konstytucyjnej. Za przykład skrajnej formy protestu uznano przypadki samookaleczenia więźniów w zakładach karnych, wskutek czego jeden z artykułów kodeksu karnego (decyzja normatywna nr 2 z 27 lutego 2008 r.) został uznany za sprzeczny z konstytucją. Podwyższenie granic dopuszczalności ograniczenia wolności wyznania posłużyło za podstawę do uznania za niekonstytucyjną przyjętą przez parlament i przedstawioną prezydentowi do zatwierdzenia ustawę „O zmianach i uzupełnieniach w niektórych aktach prawnych Republiki Kazachstanu dotyczących wolności wyznania i związków wyznaniowych”.

W rozporządzeniu nr 1 z 11 lutego 2009 r. przyjętym na wniosek prezydenta Republiki Kazachstanu wykazano, że przepisy ustawy ograni- 
czające „wolność wyznawania religii” są sprzeczne z punktem 3 art. 39 konstytucji, jako że wymienione $\mathrm{w}$ ustawie cele ograniczenia są rozszerzone $\mathrm{w}$ porównaniu $\mathrm{z}$ celami wymienionymi w konstytucji, a więc niezgodne z nimi.

W szeregu dorocznych podsumowań dotyczących zgodności prawa z konstytucją Rada Konstytucyjna podkreślała, że wprowadzając ograniczenia, ustawodawca ma obowiązek wychodzić z konstytucyjnych założeń dopuszczalności ograniczenia praw i wolności człowieka, nie wypaczając istoty konstytucyjnych praw i wolności ani nie wprowadzając takich ograniczeń, które są sprzeczne z celami określonymi w konstytucji.

Jedną z najważniejszych cech wolności słowa, informacji i środków masowego przekazu jest kompleksowość jej przedmiotu. Większość stosunków regulowanych przez jego normy jest zakorzeniona w prawie konstytucyjnym; rozwijają się one i dopełniają przez prawo cywilne, administracyjne, karne i inne. Nie można pominąć wagi aspektu finansowego, technicznego, organizacyjnego, psychologicznego i innych dotyczących efektywnej realizacji prawa o środkach masowego przekazu. Szereg gwarancji wolności słowa wynika ze stopnia rozwoju i efektywności poszczególnych instytucji społeczeństwa obywatelskiego, w tym poziomu zrozumienia prawa.

Aktualne problemy prawnego zabezpieczenia wolności słowa jest tematem licznych seminariów i okrąłych stołów, regularnie ukazuje się także biuletyn informacyjny „Ustawodawstwo i praktyka środków masowego przekazu Kazachstanu”, opublikowano także szereg powiązanych tematycznie broszur.

W tym kontekście agencja prasowa Internews-Kazakhstan nabrała pewnego doświadczenia. Obok krótkoterminowych treningów opracowano i zrealizowano projekt zaocznego kursu „Podstawy regulacji prawnych działalności dziennikarzy i środków masowego przekazu w Republice Kazachstanu". Jego treść obejmowała siedem działów tematycznych: ustawodawstwo Republiki Kazachstanu o wolności słowa i informacji; ustawy regulujące prawo do pozyskiwania i rozpowszechniania informacji; prawa i obowiązki dziennikarzy; prawne ograniczenie jawności rozpraw sądowych; obsługa medialna kampanii wyborczych; prawo o ochronie honoru, godności i dobrego imienia; podstawy państwowych regulacji organizacji i działalności środków masowego przekazu.

Opracowano także specjalny program zaplecza informacyjno-technicznego. Każdy z uczestników miał możliwość stałego kontaktu z konsultantem oraz otrzymał materiały metodyczne zawierające wymagane akty prawne, towarzyszące im zalecenia i pytania samosprawdzające. 
Świadectwem pozytywnego ukończenia w ciagu dwóch miesięcy siedmiu etapów kursu i zaliczenia testu końcowego były odpowiednie certyfikaty. Zdaniem uczestników seminarium, kurs okazał się pożyteczny. Praktyka przeprowadzania krótkich seminariów i zaocznych kursów zasługuje na szerokie rozpowszechnienie.

\title{
Bibliografia
}

Konstytucja Republiki Kazachstanu (przyjęta na ogólnonarodowym referendum 30 sierpnia 1995 r., ze zmianami i uzupełnieniami z 21 maja 2007 r.).

Ustawa „O środkach masowego przekazu” z 23 lipca 1999 r. (ze zmianami i uzupełnieniami z 27 lutego 2001 r., 3 maja 2001 r., 19 grudnia 2003 r., 8 lipca 2005 r., 10 stycznia 2006 r., 31 stycznia 2006 r., 5 lipca 2006 r., 19 czerwca 2007 r. oraz 6 lutego 2009 r.).

(Rozporządzenie z 25 lipca) „Koncepcja rozwoju konkurencyjności przestrzeni informacyjnej Republiki Kazachstanu na lata 2006-2009" (rozporządzenie prezydenta Republiki Kazachstanu z 18 sierpnia 2006 r.), „Koncepcja bezpieczeństwa informacyjnego Republiki Kazachstanu" (rozporządzenie prezydenta Republiki Kazachstanu z 10 października 2006 r.)

Europejska konwencja o telewizji transgranicznej (Seria Traktatów Rady Europy nr 132, Strasburg, 5 maja 1989).

\section{Legal Aspects of the Functioning of the Mass Media in Europe and Kazakhstan: Issues of Implementation}

\begin{abstract}
Summary
Kazakhstan is in the process of developing the legal foundations providing freedom of speech for the gathering, processing and spreading of information, as well as for the organization and activities of journalists and the mass media. There are a number of objective factors that are driving this process in Kazakhstan, including gradual democratization and modernization, entering the civilized international arena, ratification of commonly acknowledged and regional documents on human and civic freedoms and rights, transborder movement, information flow, etc. State authorities are gradually changing their attitude to the mass media; special departments dedicated to cooperation with journalists are being set up in state structures and official information is being spread by various means, including the Internet. The authorities are implementing a project providing governmental information electronically and the openness of judicial proceedings is developing in a similar manner.
\end{abstract}

